\title{
Influence of the Novel Histamine H3 Receptor Antagonist/Inverse Agonist M39 on Gastroprotection and PGE2 Production Induced by $(R)$-Alpha- Methylhistamine in C57BL/6 Mice
}

\author{
Salim M. A. Bastaki ${ }^{1 \star}$, Naheed Amir ${ }^{1}$, Małgorzata Więcek², Katarzyna Kieć-Kononowicz ${ }^{2}$ \\ and Bassem Sadek ${ }^{1 *}$ \\ ${ }^{1}$ Department of Pharmacology and Therapeutics, College of Medicine and Health Sciences, United Arab Emirates University, \\ Al-Ain, United Arab Emirates, ${ }^{2}$ Department of Technology and Biotechnology of Drugs, Faculty of Pharmacy, Jagiellonian \\ University-Medical College, Kraków, Poland
}

OPEN ACCESS

Edited by:

Raffaele Capasso,

University of Naples Federico II, Italy

Reviewed by:

Estefanía Moreno,

University of Barcelona, Spain

Enric I. Canela,

University of Barcelona, Spain

${ }^{*}$ Correspondence:

Bassem Sadek

bassem.sadek@uaeu.ac.ae

Salim M.A. Bastaki

sbastaki@uaeu.ac.ae

Specialty section:

This article was submitted to Gastrointestinal and Hepatic

Pharmacology,

a section of the journal

Frontiers in Pharmacology

Received: 28 March 2019

Accepted: 29 July 2019

Published: 12 September 2019

Citation:

Bastaki SMA, Amir N, Więcek M,

Kieć-Kononowicz K and

Sadek B (2019) Influence of the

Novel Histamine H3 Receptor

Antagonist/Inverse Agonist M39

on Gastroprotection and PGE2

Production Induced by (R)-Alpha-

Methylhistamine in C57BL/6 Mice.

Front. Pharmacol. 10:966.

doi: 10.3389/fphar.2019.00966
The role of histamine $\mathrm{H} 3$ receptors (H3Rs) in the regulation of gastroprotection and production of prostaglandin E2 (PGE2) as well as somatostatin remains contradictory. Therefore, the effects of the H3R antagonist/inverse agonist M39 on in vivo acidified ethanol-induced gastric ulcers and gastric acid secretion in the C57BL/6 mice were assessed. Results showed that acute systemic administration of H3R agonist $(R)-\alpha-$ methylhistamine (RAMH, $100 \mathrm{mg} / \mathrm{kg}$, i.g.) significantly reduced the severity of ulcer index, increased gastric acid output, and increased mucosal PGE2 production without any alteration of somatostatin concentration in gastric juice. However, only acute systemic administration of the $\mathrm{H} 2 \mathrm{R}$ agonist dimaprit (DIM, $10 \mathrm{mg} / \mathrm{kg}$, p.o.) significantly decreased the level of somatostatin measured in gastric juice. Moreover, acute systemic administration of M39 $(0.3 \mathrm{mg} / \mathrm{kg}$, i.g.) abrogated the RAMH-induced increase of acid output as well as PGE2 production, but not the DIM $(10 \mathrm{mg} / \mathrm{kg}$, i.g.)-stimulated acid secretion, indicating that RAMH as well as M39 modulate the gastroprotective effects through interactions with histamine H3Rs. The present findings indicate that agonistic interaction with $\mathrm{H} 3 \mathrm{Rs}$ is profoundly involved in the maintenance of gastric mucosal integrity by modulating PGE2 as well as gastric acid secretion, with no apparent role in the regulation of the inhibitory influence of somatostatin.

Keywords: H3 receptor, antagonist, M39, ulcer, C57BL/6 mice

\section{INTRODUCTION}

Peptic ulcer is a chronic disease affecting up to $10 \%$ of the world's population, and the formation of peptic ulcers depends on the presence of increased acidic gastric juice and the decreased mucosal defenses (Kuna et al., 2019). Non-steroidal anti-inflammatory drugs (NSAIDs) and Helicobacter pylori (H. pylori) infection are the two main factors disrupting the mucosal resistance to injury. Currently available conventional treatments of peptic ulcers include numerous pharmaceutical agents such as proton pump inhibitors, histamine $\mathrm{H} 2$-receptor antagonists, anticholinergics, antacids, antimicrobial 
agents, sucralfate, and bismuth, all of which are not fully effective, and are associated with numerous side effects including impotence, arrhythmia hematopoietic alterations hypersensitivity and gynecomastia (Chanda et al., 2011; Palle et al., 2018). Consequently, there is still a strong need for new pharmacologically active entities for the therapeutic management of peptic ulcer. Histamine exerts its biological activities through interaction with four distinct histamine receptors (H1R-H4R) that belong to the G-protein coupled receptor (GPCR) family (Lovenberg et al., 1999; Panula et al., 2015; Sadek and Stark, 2015; Sadek et al., 2016b). H1R and $\mathrm{H} 2 \mathrm{R}$ are found in the brain and periphery. Although H4Rs are present in the brain, they are predominately expressed in mast cells and leucocytes, whereas H3Rs are abundant in CNS (Arrang et al., 1983; Arrang et al., 1985; Arrang et al., 1987a; Arrang et al., 1987b; Arrang et al., 1988; Arrang et al., 2007; Panula et al., 2015). H3Rs are coupled to $G_{i} / G_{o}$-proteins and act as auto-receptors that control the synthesis and release of histamine in the CNS, while activation of H1R and H2R mediates slow excitatory postsynaptic potentials (Arrang et al., 1983; Arrang et al., 1985; Arrang et al., 1987b; Sadek and Stark, 2015). Furthermore, H3Rs functioning as heteroreceptors can also regulate the release of other neurotransmitters like acetylcholine, glutamate, GABA, norepinephrine, serotonin, dopamine in variable brain regions (Brown et al., 2001). Mounting preclinical experimental evidences related numerous functional and behavioral effects to central H3R-mediation. The activation of such cerebral sites appears to stimulate a waking effect in cats (Schwartz et al., 2003; Lin et al., 2008; Lin et al., 2011), modulation of locomotor activity, anticonvulsant, antinociceptive, and procognitive actions in mice and rats (Clapham and Kilpatrick, 1993; Yokoyama et al., 1993; Clapham and Kilpatrick, 1994; Malmberg-Aiello et al., 2003; Sadek et al., 2013; Sadek et al., 2014a; Sadek et al., 2014b; Sadek et al., 2015; Sadek and Stark, 2015; Sadek et al., 2016a; Sadek et al., 2016b; Sadek et al., 2016c). Interestingly, several polymorphisms have been detected for H3Rs (Hancock et al., 2003; Bongers et al., 2007), and H3Rs were found to be expressed in dimers (Shenton et al., 2005; Bakker et al., 2006) as well as co-expressed with other GPCRs, e.g. dopamine D1- or D2 receptors and adenosine $\mathrm{A} 2 \mathrm{~A}$ receptors in form of heteromers, and were linked with their modulating effects on several brain neurotransmitters, and therefore, their influence in mitigating numerous brain disorders (Ferrada et al., 2008; Ferrada et al., 2009; Moreno et al., 2011; Rodriguez-Ruiz et al., 2017; MarquezGomez et al., 2018). Notably, complexity of histamine H3R biology e.g. many isoforms, constitutive activity, the aforementioned heteromerization with other receptors (dopamine D2, D1, adenosine A2A), and pharmacology make it difficult to realize and evaluate the therapeutic potential of H3R antagonists (Lazewska and Kiec-Kononowicz, 2018).

Moreover, H3R has been identified in the gastrointestinal tract of the rat by immunohistochemistry, as immunoreactivity to H3R was exclusively localized to the endocrine cells scattered in the gastrointestinal mucosa, with positive cells being prominently abundant in the gastric fundus, while they were rarely found in the other regions (Grandi et al., 2008).

Contrary, peripheral administration of the selective $H 3 R$ agonist $(R)$ - $\alpha$-methylhistamine (RAMH) was found to inhibit pentagastrin-, 2-deoxy-D-glucose-, and peptone meal-stimulated gastric acid secretion in conscious cats as well as pentagastrin- and bombesin-induced hypersecretion in the conscious dog (Bado et al., 1991; Soldani et al., 1993). The latter inhibitory effects were also found to be antagonized by co-administration of the H3R antagonist thioperamide (Soldani et al., 1993). Moreover, numerous previous in-vitro experimental models of gastric injury showed that H3R agonist RAMH exerts protective effects with controversial interpretations (Morini et al., 1995a; Morini et al., 1995b; Morini et al., 1997; Morini et al., 2008b). For instance, RAMH was likely to inhibit acid secretion via the suppression of histamine in isolated rat fundic enterochromafin-like cells, whereas an increased acid secretion secondary to reduced somatostatin secretion is reported in isolated mouse stomach (Morini et al., 1995a; Morini et al., 1995b; Morini et al., 1997; Morini et al., 2008b). Furthermore, early in-vivo experiments showed that RAMH also potently inhibits gastric secretion by a number of indirect stimuli, e.g. vagal stimulation or pentagastrin (Bado et al., 1991; Yokotani et al., 2000). In addition, the role of H3Rs in the gastric mucosal gastrin expression and release by inhibiting secretion of somatostatin is still unclear, since the mechanism of action underlying this phenomenon remains unknown and is still a matter of study even though the presence of H3Rs on parasympathetic nerve terminals or on gastric paracrine cells has been proposed (Soll and Walsh, 1979; Bado et al., 1991; Soldani et al., 1993; Soldani et al., 1994; Coruzzi et al., 2001). In addition, unclear data were obtained with two highly selective H3R agonists, namely imetit (Garbarg et al., 1992) and immepip (Vollinga et al., 1994), which failed to share the gastroprotective effect of RAMH towards $0.6 \mathrm{~N} \mathrm{HCl}$-induced gastric damage in rat. However, it is well-known that many imidazole-containing ligands, including immepip and imetit, display affinity for the H4R (Lim et al., 2005), indicating that it might be postulated that histamine $\mathrm{H} 4$ receptormediated mechanisms may have influenced the interpretation of the observed results for immepip and imetit (Coruzzi et al., 2011). The H4R was primarily identified on immunocompetent cells and cells of the hematopoietic lineage, such as mast cells, eosinophils, basophils, dendritic cells and $\mathrm{T}$ cells and a primary role in the inflammatory responses was postulated (Leurs et al., 2009). Therefore, H4R antagonists are under development as novel antiallergic and antiinflammatory drugs (Thurmond et al., 2008; Zampeli and Tiligada, 2009; Sadek and Stark, 2015). Additionally, H4R expression was detected by immunohistochemistry in different areas of the gut (Cianchi et al., 2005; Sander et al., 2006; Breunig et al., 2007; Boer et al., 2008; Morini et al., 2008a) and protective effects have been evidenced, by the use of the H4R antagonist JNJ7777120 in various rodent models of gastric and intestinal damage (Thurmond et al., 2004; Varga et al., 2005; Coruzzi et al., 2007), demonstrating the involvement of the H4Rs in gastrointestinal inflammation and ulcerogenesis (Coruzzi et al., 2012).

To date, the potential contribution of a central H3R-mediated in-vivo regulatory influence in affecting gastric acid secretion has not been extensively explored and as a result cannot be ruled out completely. The latter considerations together with the aforementioned controversies in results obtained so far encouraged us to investigate the possible involvement of H3Rs in the control of gastric secretory function. Therefore, the objective of the current study was to determine whether interactions with H3Rs mediate in vivo gastroprotection applying the acidified 
ethanol-induced gastric ulcers and gastric acid secretion model in C57BL/6 mice, and following intragastric (i.g.) administration of the potent and selective H3R antagonist/inverse agonist M39 in presence and absence of the selective and potent $\mathrm{H} 3 \mathrm{R}$ agonist RAMH (Figure 1). Furthermore, the modulating effects of both H3R compounds on synthesis of somatostatin as well the production of prostaglandin E2 (PGE2) were investigated.

\section{MATERIAL AND METHODS}

\section{Animals}

C57BL/6 mice were purchased from Jackson Laboratory, Boulevard, Bethesda, MD 20892-4874, USA. They were bred at our animal facility. Adult male C57BL/6 mice (14-15 weeks) weighing 25-28 g were fasted for $24 \mathrm{~h}$ in wire mesh cages to avoid coprophagy but had free access to water ad libitum. The temperature of the animal room were maintained at $22 \pm 2{ }^{\circ} \mathrm{C}$ and with a $12-12 \mathrm{~h}$ dark-light cycle. This study was carried out in accordance with the recommendations of the European Communities Council Directive of 24 November 1986 (86/609/EEC), and was approved by the Institutional Animal Ethics Committee in the College of Medicine and Health Sciences/ United Arab Emirates (Approval No. A38-13). All efforts were made to minimize animal suffering and to reduce the number of animals used.

\section{Chemicals and Drugs}

The H3R antagonist/inverse agonist 3-(1H-imidazol-4-yl) propyl but-3-en-1-ylcarbamate (M39) was synthesized by us in the Department of Technology and Biotechnology of Drugs (Kraków, Poland) as described previously (Wiecek et al., 2011)

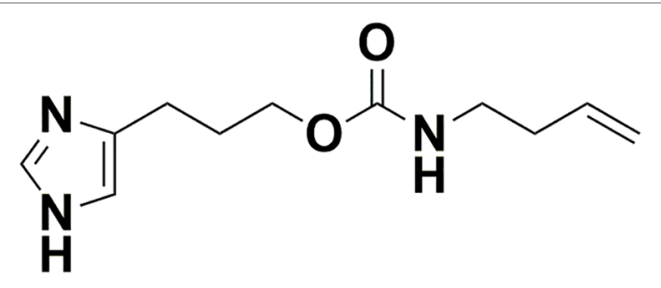

M39

$$
\begin{gathered}
\mathrm{ED}_{50}=2.7 \pm 1.0[\mathrm{mg} / \mathrm{kg}, \text { p.o. }]^{\mathrm{a}} \\
(h \mathrm{H} 3 \mathrm{R}) \mathrm{p} K_{\mathrm{i}}=7.26^{\mathrm{a}} \\
(g \mathrm{pH} 1 \mathrm{R}) \mathrm{pA}_{2}<4^{\mathrm{a}} \\
(g p \mathrm{H} 2 \mathrm{R}) \mathrm{pD}_{2}<4^{\mathrm{a}} \\
(h \mathrm{H} 4 \mathrm{R}) \mathrm{p} K_{\mathrm{i}}=6.42^{\mathrm{a}}
\end{gathered}
$$

FIGURE 1 | Structure, in-vivo potency, and in-vitro antagonist affinities of H3R antagonist/inverse M39. aValues previously published (Wiecek et al., 2011; Sadek et al., 2013). Values for H1R and H2R were tested on guinea pig (gp).
(Figure 1). The compound M39 was synthesized by a modified Curtius reaction. In this reaction 4-pentenoic acid was reacted with diphenyl phosphorazidate (DPPA) under basic conditions leading to in situ obtained isocyanate intermediate, which then was reacted with 3-(1H-imidazol-yl)propanol hydrochloride to yield M39 (Wiecek et al., 2011).

All other drugs and chemicals were purchased from SigmaAldrich (St Louis, Missouri, USA). All drug solutions were freshly prepared. The enzyme immunoassay kit of Somatostatin was purchased from Phoenix Pharmaceuticals, Inc., Burlingame, CA 94010, USA. Enzyme immunoassay kit of PGE2 was purchased from R\&D Systems, Minneapolis, MN, USA.

\section{Gastric Acid Secretion In Vivo}

Mice were initially anaesthetized with pentobarbitone $(70 \mathrm{mg} /$ $\mathrm{kg}$ ) intraperitoneally (i.p.). Following general anesthesia, the pylorus was ligated according to the method of Shay et al, 1945 (Shay et al., 1945; Wiecek et al., 2011). Briefly, after the ligation, the animals were assigned into six different groups of six mice as follows: group 1: control, pretreated with distilled water (DW), group 2: RAMH (100 $\mathrm{mg} / \mathrm{kg}$, i.g.), group 3: H2R agonist DIM (10 mg/kg, i.g.), group 4: M39 (0.3 mg/ $\mathrm{kg}$, i.g.), group 5: M39 (0.3 mg/kg, i.g.)+RAMH (100 mg/kg, i.g.), and group 6: M39 (0.3 mg/kg, i.g.)+DIM (10 mg/kg, i.g.).

All the drug solutions were administered to the animals by gastric gavage. However, both groups 5 and 6 received H3R antagonist/inverse agonist M39 $(0.3 \mathrm{mg} / \mathrm{kg})$ followed by 15 min later administration of RAMH or DIM, respectively. The dose of $0.3 \mathrm{mg} / \mathrm{kg}$ of M39 was selected based on a dose response $(0.3-3.0 \mathrm{mg} / \mathrm{kg})$ pilot study as well as according to previous study conducted in Wistar rats (Morini et al., 2000). After $4 \mathrm{~h}$, the animals were sacrificed by cervical dislocation and the gastric juice was collected for somatostatin assay and gastric contents were titrated against $0.01 \mathrm{M}$ sodium hydroxide for acid output which was calculated and expressed as $\mathrm{mmol} / 4 \mathrm{~h}$.

\section{Assay of Somatostatin in Gastric Juice}

Competitive Enzyme immunoassay of somatostatin in gastric juice was performed according to manufacturer's protocol. Briefly, the immunoplate was pre-coated with secondary antibody and the nonspecific binding sites were blocked. The secondary antibody was allowed to bind to the Fc fragment of the primary antibody whose Fab fragment was competitively bound by both biotinylated peptide and peptide standard or targeted peptide in samples during 2 incubation at room temperature $\left(20-23^{\circ} \mathrm{C}\right)$ on orbital shaker at $300-400 \mathrm{rpm}$. The interaction of biotinylated peptide with streptavidin-horseradish peroxidase (SA-HRP) was catalyzed by the substrate solution. The intensity of the color is directly proportional to the amount of biotinylated peptide- SA-HRP complex but inversely proportional to the amount of the peptide in standard solutions or samples. The color intensity was read at $450 \mathrm{~nm}$ with a microplate reader (Tecan Group Ltd., Männedorf, Switzerland). Somatostatin concentration was expressed as nanogram per $\mathrm{ml}$ of gastric juice. 


\section{Gastric Acid Ulcer In Vivo}

Acidified ethanol (AE; 60\% ethanol in $150 \mathrm{mM}$ hydrochloric acid) was used to induce gastric ulcers in the mice. The mice were divided into four different groups of 6 animals each. Each group received either DW (control), or RAMH (100 mg kg), or M39 $(0.3 \mathrm{mg} / \mathrm{kg}) 15 \mathrm{~min}$ prior to RAMH $(100 \mathrm{mg} / \mathrm{kg})$ administration as a gastric gavage. After $30 \mathrm{~min}$ of DW or drug administration, AE was given orally to each animal at a dose of $0.2 \mathrm{ml}$ per mouse and the animals were killed $1 \mathrm{~h}$ later by cervical dislocation. The abdomen was incised and the stomach removed. The stomach was cut open along the greater curvature and rinsed with saline to remove any adherent food particles and mucus. The opened stomach was then spread on a sheet of cork so as to have a clear macroscopic view of the gastric mucosa. The total lengths of the haemorrhagic lesions, which were approximately $1 \mathrm{~mm}$ in width and formed in the glandular portion of the gastric mucosa, were taken as ulcer index (UI). An observer unaware of the drug treatments confirmed the ulcer index. The use of $60 \%$ ethanol in $150 \mathrm{mM} \mathrm{HCl}$ as an ulcerogenic agent was based on our earlier observation and of others that ethanol $50 \%$ and over provided a reproducible model of gastric damage (Nishida et al., 1994; Mercer et al., 1995; Chandranath et al., 2002; Bastaki et al., 2003).

\section{Preparation of Gastric Mucosal Homogenate}

Briefly, after dissection, stomachs were washed with ice-cold PBS, and the gastric mucosa was rapidly scraped from the underlying tissue layers of stomach on ice. The mucosa was weighed, minced by forceps, and homogenized with 3 volumes of cold phosphate buffer (PBS $0.1 \mathrm{~mol} / \mathrm{L}, \mathrm{pH} 7.4$, containing $1 \mathrm{mM}$ EDTA and $10 \mu \mathrm{M}$ indomethacin) per gram of tissue using a polytron homogenizer (IKA laboratory, Germany).

\section{Assay of PGE2 in Gastric Mucosa}

Competitive Enzyme immunoassay of PGE2 in gastric mucosal was performed according to manufacturer's protocol. This assay was based on the forward sequential competitive binding technique in which PGE2 present in a sample competed with horseradish peroxidase (HRP)-labeled PGE2 for a limited number of binding sites on a mouse monoclonal antibody. PGE2 in the sample was allowed to bind to the antibody in the first incubation of one hour at room temperature on a horizontal orbital microplate shaker $(0.12$ " orbit $)$ at $500 \pm 50 \mathrm{rpm}$. During the second incubation, HRP-labeled $\mathrm{PGE}_{2}$ was bound to the remaining antibody sites. Unbound materials were washed and substrate solution was added to the wells to determine the bound enzyme activity. The color development was stopped, and the absorbance was read at $450 \mathrm{~nm}$. The intensity of the color was inversely proportional to the concentration of PGE2 in the sample. PGE2 concentration was expressed as picogram per milligram of mucosal tissue.

\section{Statistical Analysis}

Data was analyzed statistically using SPSS 25.0 software (IBM Middle East, Dubai, UAE). The means of the data are presented with the standard error mean (SEM). The results were analyzed using independent $t$-test to determine the significance of the mean between the groups. Values of $P<0.05$ were considered significant.

\section{RESULTS}

\section{Acidified Ethanol-Induced Gastric Mucosal Lesions \\ Macroscopy}

Acidified ethanol determined the formation of red to black linear streaks in the glandular portion of the stomach of vehicle-treated group (ulcer index of $35.5 \pm 4, \mathrm{n}=6$ ) (Figures 2 and 3). Mucosal damage caused by acidified ethanol was substantially reduced by $\mathrm{RAMH}$ at the dose of $100 \mathrm{mg} / \mathrm{kg}$ (ulcer index of $6.0 \pm 1.46, \mathrm{n}=6$; $P<0.001)$. Similarly, M39 when administered alone at a dose of $0.3 \mathrm{mg} / \mathrm{kg}$ significantly reduced the mucosal damage (ulcer index of $9.0 \pm 1.41, \mathrm{n}=6 ; P<0.001)$ (Figures 2 and 3). However, RAMH and M39 $(0.3 \mathrm{mg} / \mathrm{kg})$ failed to completely abrogate each other's protections when compared to vehicle-, RAMH(100mg/ $\mathrm{kg})$-, M39(0.3mg)-group with ulcer index of $15.67 \pm 1.44, \mathrm{n}=6$; both $P<0.05$ for RAMH(100mg)+M39(0.3mg)-treated group versus RAMH- or M39(0.3mg)-treated group) (Figures 2 and 3).

\section{PGE2 Synthesis}

The observed results show that both the H3R agonist RAMH (100 mg/kg) and M39 (0.3 mg/kg) administered separately significantly increased the synthesis of mucosal PGE2 with values of $38971.17 \pm 624.44$ and $37828.98 \pm 782.45 \mathrm{pg} / \mathrm{mg}$ of gastric mucosa, respectively $(P>0.001$ for RAMH- and M39-treated group versus vehicle-treated group), respectively. However, co-administration of both M39 and RAMH abrogated each other's stimulating effect on PGE2 synthesis with a value of $26650.72 \pm$ $3068.16 \mathrm{pg} / \mathrm{mg}$ ( $\mathrm{p}=0.65$ for M39+RAMH-treated group versus vehicle-treated group) (Figure 4).

\section{Somatostatin Synthesis}

The results observed show that only DIM significantly decreased the synthesis of somatostatin $(12.83 \pm 0.36 \mathrm{ng} / \mathrm{mL}$ for vehicle-treated group versus $9.21 \pm 1.25 \mathrm{ng} / \mathrm{mL}$ for DIM-treated group; $P<0.05)$. However, RAMH and M39 (0.3 and $3 \mathrm{mg}$ ) failed to modulate the biosynthesis of somatostatin with values of $12.47 \pm 1.33,13.18$ \pm 0.80 , and 11.21 \pm 1.10 , respectively (all $P$ values $>0.05$ ) (Figure 5).

\section{Gastric Acid Secretion}

In the juice present in the stomach, the H2R agonist DIM and the H3R agonist RAMH caused a significant increase in the volume of gastric juice with a concomitant marked and significant increase in the amount of titratable acidity (Figure 6). The stimulation of acid secretion by RAMH, was completely reversed by prior treatment with the H3R antagonist/inverse agonist M39 ( $\mathrm{p}=0.96$ for vehicle-treated group versus $\mathrm{RAMH}+\mathrm{M} 39(0.3 \mathrm{mg})$ treated group) (Figure 6). However, M39 (0.3 mg/kg) failed to reverse the effect observed by DIM ( $\mathrm{p}=0.63$ for DIM-treated group versus DIM+M39(0.3mg)-treated group) (Figure 6). In addition, H3R antagonist/inverse agonist M39 (0.3 and $3 \mathrm{mg} / \mathrm{kg})$ 


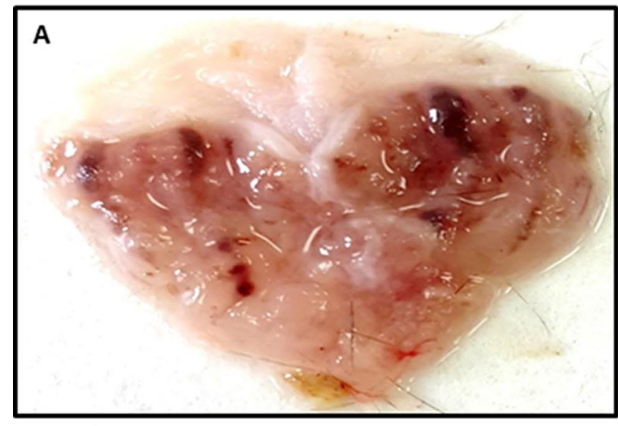

Control

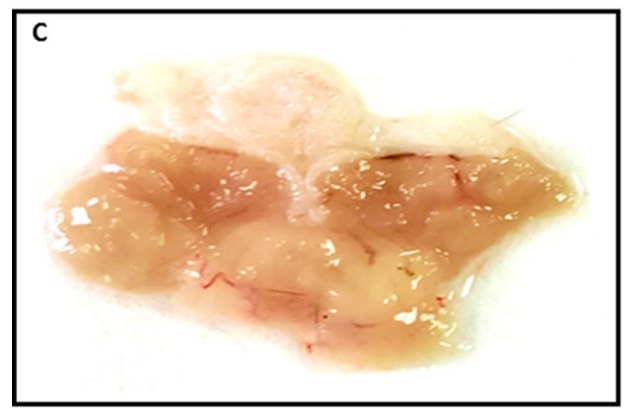

M39 (0.3 mg)

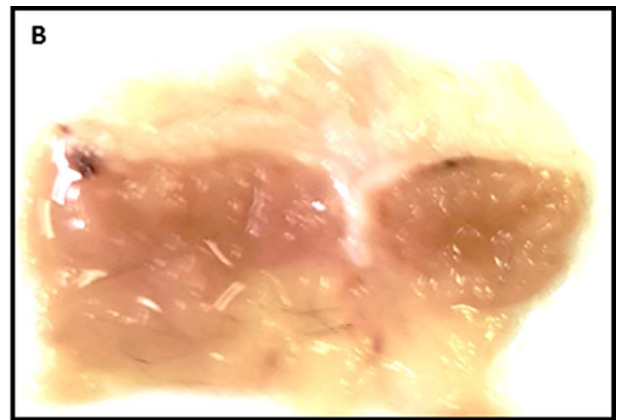

RAMH (100 mg)

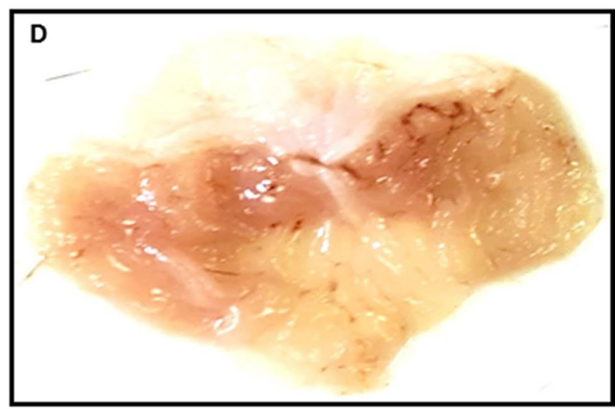

M39 (0.3 mg) + RAMH (100 mg)

FIGURE 2 | Photomicrographs of stomachs showing the effect of vehicle, H3R agonist (R)- $\alpha$-methylhistamine, and test compound M39 on stomach ulcer of C57BL/6 mice. Micrographs are the results of five to six such experiments. showing the effect on acidified ethanol in (A) vehicle-, (B) RAMH(100mg/kg)-, (C) M39(0.3mg)-, and (D) M39(0.3mg)+RAMH(100mg)-treated group in reducing the stomach ulcers.

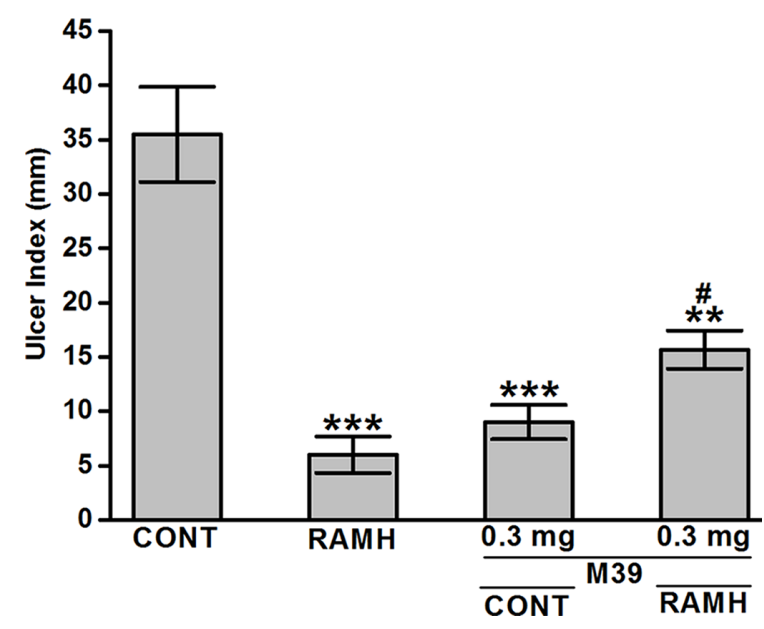

FIGURE 3 | Effects of vehicle, H3R agonist $(R)$ - $\alpha$-methylhistamine, and test compound M39 on acidified ethanol-induced ulcer index in C57BL/6 mice. ${ }^{\star \star} P<0.01$ vs. vehicle-treated group. ${ }^{\star \star \star} P<0.001$ vs. vehicle-treated group. $\# P<0.05$ vs. RAMH- or M39(0.3mg)-treated group. Data represent mean \pm $\operatorname{SEM}(\mathrm{n}=5-6)$.

had no effect on titratable acidity when administered alone as compared to vehicle-treated group $(\mathrm{p}=0.36$ and $\mathrm{p}=0.36$, for $\mathrm{M} 39(0.3 \mathrm{mg})$-treated group versus vehicle-treated group and $\mathrm{M} 39(3 \mathrm{mg})$-treated group versus vehicle-treated group, respectively) (Figure 6).

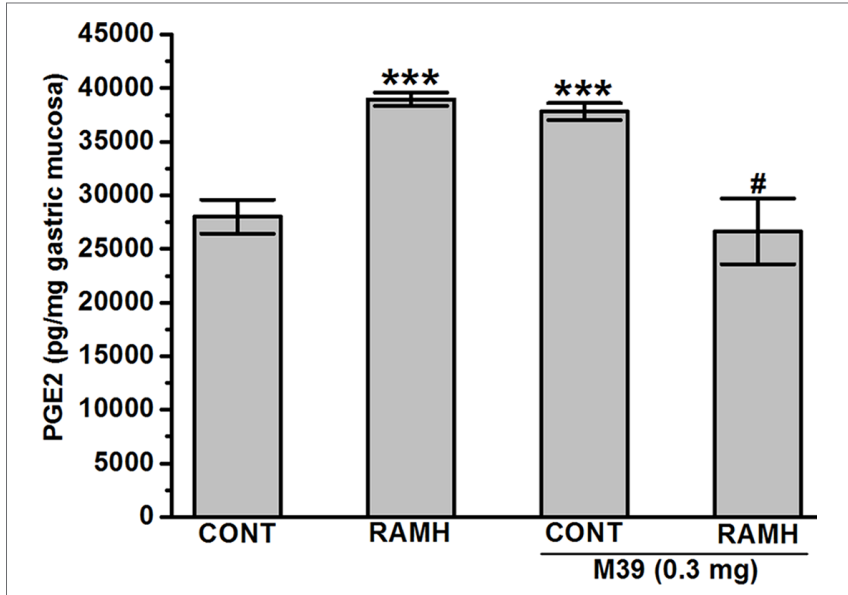

FIGURE 4 | Effect of vehicle, H3R agonist $(R)$ - $\alpha$-methylhistamine, and test compound M39 on PGE2 synthesis in the stomach mucosa of C57BL/6 mice. ${ }^{\star \star \star} P<0.001$ vs. vehicle-treated group. ${ }^{\#} P<0.05$ vs. RAMH- or M39(0.3mg)-treated group. Results are expressed as the mean \pm standard error of six replicates.

\section{DISCUSSION}

The current study indicates that RAMH efficiently preserves the integrity of mice gastric mucosa against damage with acidified ethanol, as measured using macroscopic evaluation (Figure 2). In the current in-vivo gastric ulcer model, the H3R agonist 


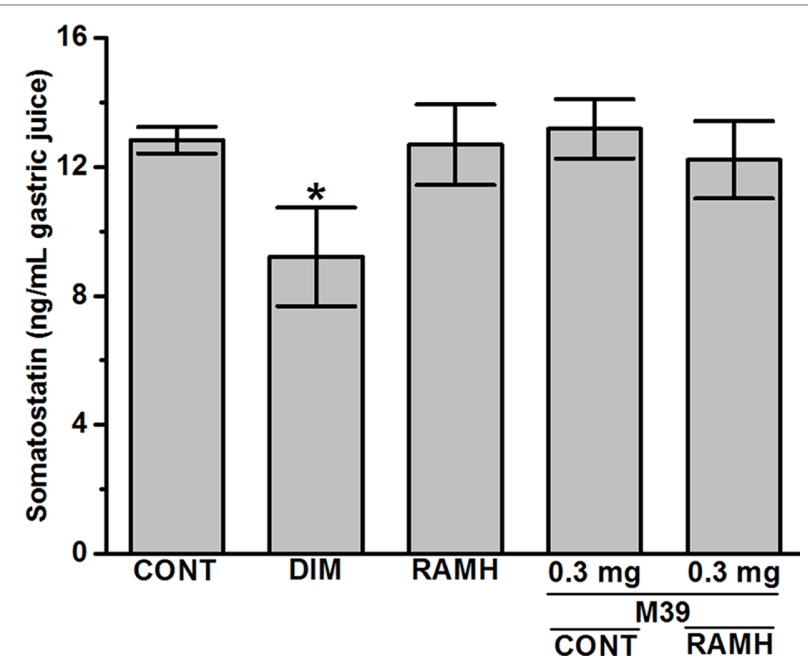

FIGURE 5 | Effects of vehicle, H2R agonist dimaprit, H3R agonist $(R)-\alpha$-methylhistamine, and test compound M39 on gastric somatostatin concentration in C57BL/6 mice. Data represent mean \pm SEM $(n=5-6)$. ${ }^{*} P<$ 0.05 vs. vehicle-treated group.

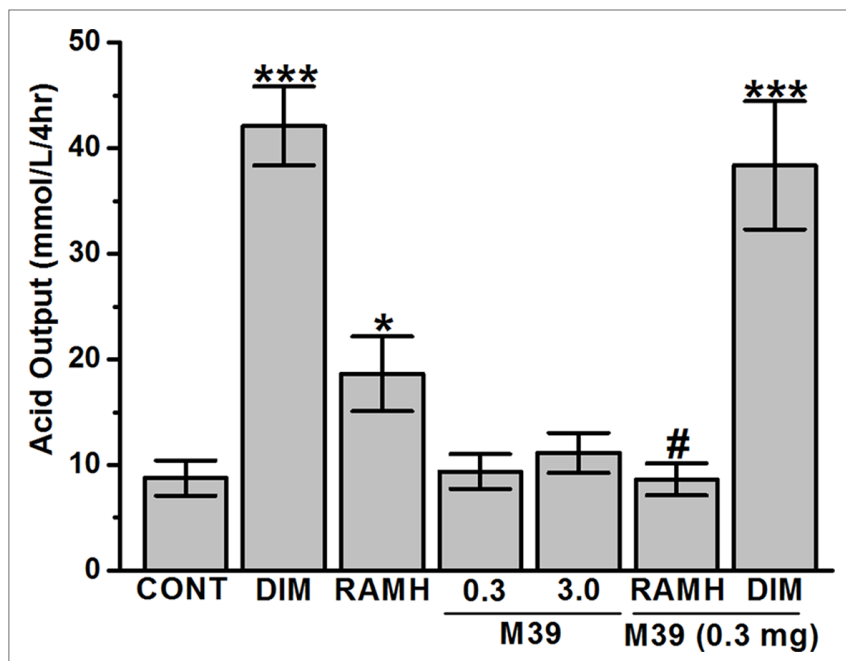

FIGURE 6 | Effects of vehicle, H2R agonist dimaprit, H3R agonist $(R)-\alpha-$ methylhistamine, and test compound M39 on gastric acid secretion in the stomachs of C57BL/6 mice. Data represent mean \pm SEM $(n=5-6)$. ${ }^{\star} P<$ 0.05 vs. vehicle-treated group. ${ }^{\star \star \star} P<0.001$ vs. vehicle-treated group. $\# P<0.05$ vs. RAMH-treated group.

RAMH and the H3R antagonist/inverse agonist M39 exhibited comparable gastroprotective effects as obviously observed by ulcer indices (Figure 3). Moreover, the results observed show that the gastroprotective effect provided by H3R agonist RAMH was partly reversed when mice were pretreated with M39 as measured on the level of ulcer index, indicating that, in addition to histaminergic pathways through activation of H3Rs, the protective effects might be attributed to mechanisms other than histaminergic neurotransmission. These results are in agreement with a previous study which showed that H3R is involved in the protection of rat stomach against concentrated hydrochloric acid.
However, the functional role of the H4R is still to be defined, although selective agonists induce proulcerogenic effects under hydrochloric acid challenge (Coruzzi et al., 2011). Furthermore, both compounds when administered separately significantly increased the level of synthesized PGE2, an effect that might explain the gastroprotection provided by both compounds (Figure 4). Interestingly, the stimulating effect observed for RAMH on PGE2 synthesis was completely abolished when mice were pretreated with the potent H3R antagonist M39 (Figure 4). However, the H3R agonist RAMH as well as the H3R antagonist/ inverse agonist M39 failed in the current study to modify the synthesis of somatostatin (Figure 5). The latter results are in disagreement with previous studies in which modulation of H3Rs resulted in a significant alteration of somatostatin synthesis, demonstrating that the mechanisms responsible for the protective action observed for RAMH and H3R antagonist/ inverse agonist M39 appear to be unrelated to their effects on somatostatin synthesis (Morini et al., 1995a; Morini et al., 1995b; Morini et al., 1997; Morini et al., 2000). Moreover, protection by RAMH is not attributable to a modulation in gastric acidity, since RAMH increased acid production and secretion, although significantly lower than the effect observed for the H2R agonist DIM (Figure 6). Furthermore, the H3R antagonist/inverse agonist M39 failed to modify gastric acid secretion which is in agreement with previous studies in which ciproxifan was found to be not effective in increasing or decreasing gastric acid secretion (Morini et al., 2000). Interestingly, the effect of RAMH, but not of DIM, on increasing gastric acid secretion was completely abrogated when mice were pretreated with M39 (Figure 6). These observations clearly indicate that there is no association between the effects observed for RAMH and M39 on gastric acid secretion and their influence on the susceptibility of the mucosa to lesion formation. Notably, there is still some debate as to whether the stimulation of gastric acid secretion evoked by RAMH in rodents is attributable to H3R activation (Vuyyuru and Schubert, 1997; Coruzzi and Bertaccini, 1998). However, the present failure of H3R antagonist/inverse agonist M39 to influence RAMHstimulated acid secretion at doses causing a complete inhibition of RAMH-induced increase of PGE2 synthesis appears to rule out the involvement of H3Rs in the acid secretory response to $\mathrm{RAMH}$. Therefore, caution is required when interpreting the effects observed for H3R agonists or antagonists/inverse agonists in preclinical ulcer models. Accordingly, the differences in animal species together with the type of experimental conduct and the routes by which the test compounds are administered should be considered for comparison when interpreting results observed. Additionally, it should be taken into consideration that RAMH and M39 are likely to differ significantly in their pharmacokinetic properties when it comes to testing them in in-vivo models.

\section{CONCLUSION}

The partial M39-provided inhibition of the gastroprotection exerted by RAMH validate the hypothesis that RAMH is capable of counteracting mucosal damage mediated through histamine H3Rs. However, here we present the first evidence that agonistic 
interaction with H3Rs are actively involved in the maintenance of gastric mucosal integrity by modulating PGE2 as well as gastric acid secretion, with no apparent role in the regulation of inhibitory influence of somatostatin. However, the observed results showed that M39 reverses the effects of RAMH on gastroprotection and PGE2 production, demonstrating that it is still difficult to provide a conclusion since both compounds were able to show effects on their own, and combination of both counteracts the effects of either alone. Therefore, the exact mechanistic background for the mediated protective effects of RAMH as well as M39 still continues to be a challenge.

\section{DATA AVAILABILITY}

The raw data supporting the conclusions of this manuscript will be made available by the authors, without undue reservation, to any qualified researcher.

\section{REFERENCES}

Arrang, J. M., Devaux, B., Chodkiewicz, J. P., and Schwartz, J. C. (1988). H3-receptors control histamine release in human brain. J. Neurochem. 51 (1), 105-108. doi: 10.1111/j.1471-4159.1988.tb04841.x

Arrang, J. M., Garbarg, M., Lancelot, J. C., Lecomte, J. M., Pollard, H., Robba, M., et al. (1987a). Highly potent and selective ligands for histamine H3-receptors. Nature 327 (6118), 117-123. doi: 10.1038/327117a0

Arrang, J. M., Garbarg, M., and Schwartz, J. C. (1983). Auto-inhibition of brain histamine release mediated by a novel class (H3) of histamine receptor. Nature 302 (5911), 832-837. doi: 10.1038/302832a0

Arrang, J. M., Garbarg, M., and Schwartz, J. C. (1985). Autoregulation of histamine release in brain by presynaptic H3-receptors. Neuroscience 15 (2), 553-562. doi: 10.1016/0306-4522(85)90233-7

Arrang, J. M., Garbarg, M., and Schwartz, J. C. (1987b). Autoinhibition of histamine synthesis mediated by presynaptic H3-receptors. Neuroscience 23 (1), 149-157. doi: 10.1016/0306-4522(87)90279-X

Arrang, J. M., Morisset, S., and Gbahou, F. (2007). Constitutive activity of the histamine H3 receptor. Trends. Pharmacol. Sci. 28 (7), 350-357. doi: 10.1016/j. tips.2007.05.002

Bado, A., Hervatin, F., and Lewin, M. J. (1991). Pharmacological evidence for histamine $\mathrm{H} 3$ receptor in the control of gastric acid secretion in cats. Am. J. Physiol. 260 (4 Pt 1), G631-G635. doi: 10.1152/ajpgi.1991.260.4.G631

Bakker, R. A., Lozada, A. F., van Marle, A., Shenton, F. C., Drutel, G., Karlstedt, K., et al. (2006). Discovery of naturally occurring splice variants of the rat histamine H3 receptor that act as dominant-negative isoforms. Mol. Pharmacol. 69 (4), 1194-1206. doi: 10.1124/mol.105.019299

Bastaki, S. M., Hasan, M. Y., Chandranath, S. I., Schmassmann, A., and Garner, A. (2003). PD-136,450: a CCK2 (gastrin) receptor antagonist with antisecretory, anxiolytic and antiulcer activity. Mol. Cell Biochem. 252 (1-2), 83-90. doi: 10.1023/A:1025566919581

Boer, K., Helinger, E., Helinger, A., Pocza, P., Pos, Z., Demeter, P., et al. (2008). Decreased expression of histamine $\mathrm{H} 1$ and $\mathrm{H} 4$ receptors suggests disturbance of local regulation in human colorectal tumours by histamine. Eur. J. Cell Biol. 87 (4), 227-236. doi: 10.1016/j.ejcb.2007.12.003

Bongers, G., Bakker, R. A., and Leurs, R. (2007). Molecular aspects of the histamine H3 receptor. Biochem. Pharmacol. 73 (8), 1195-1204. doi: 10.1016/j. bcp.2007.01.008

Breunig, E., Michel, K., Zeller, F., Seidl, S., Weyhern, C. W., and Schemann, M. (2007). Histamine excites neurones in the human submucous plexus through activation of H1, H2, H3 and H4 receptors. J. Physiol. 583 (Pt 2), 731-742. doi: 10.1113/jphysiol.2007.139352

Brown, R. E., Stevens, D. R., and Haas, H. L. (2001). The physiology of brain histamine. Prog. Neurobiol. 63 (6), 637-672. doi: 10.1016/S0301-0082(00)00039-3

\section{AUTHOR CONTRIBUTIONS}

BS and SAB were responsible for the study concept, design, and acquisition and analysis of data. NA conducted all experiments. KK-K and MW were responsible for the generation, synthesis, and pharmacological in vitro characterization of the test compound M39. BS and SAB drafted the manuscript. KK-K, MW, and NA critically revised the manuscript. All authors critically reviewed content and approved the final version of the manuscript for publication.

\section{FUNDING}

SB and BS were supported by intramural funds from the College of Medicine and Health Sciences and the Office of Graduate Studies and Research, UAE University. The authors acknowledge the partial support of Jagiellonian University statutory funds (K/ZDS/007121) and EU COST Action MuTaLig CA15135 to KK-K and MW.

Chanda, S., Baravalia, Y., and Kaneria, M. (2011). Protective effect of Polyalthia longifolia var. pendula leaves on ethanol and ethanol/ $\mathrm{HCl}$ induced ulcer in rats and its antimicrobial potency. Asian Pac. J. Trop. Med. 4 (9), 673-679. doi: 10.1016/S1995-7645(11)60172-7

Chandranath, S. I., Bastaki, S. M., and Singh, J. (2002). A comparative study on the activity of lansoprazole, omeprazole and PD-136450 on acidified ethanol- and indomethacin-induced gastric lesions in the rat. Clin. Exp. Pharmacol. Physiol. 29 (3), 173-180. doi: 10.1046/j.1440-1681.2002.03626.x

Cianchi, F., Cortesini, C., Schiavone, N., Perna, F., Magnelli, L., Fanti, E., et al. (2005). The role of cyclooxygenase-2 in mediating the effects of histamine on cell proliferation and vascular endothelial growth factor production in colorectal cancer. Clin. Cancer Res. 11 (19 Pt 1), 6807-6815. doi: 10.1158/10780432.CCR-05-0675

Clapham, J., and Kilpatrick, G. J. (1993). Histamine H3 receptor-mediated modulation of water consumption in the rat. Eur. J. Pharmacol. 232 (1), 99-103. doi: 10.1016/0014-2999(93)90733-X

Clapham, J., and Kilpatrick, G. J. (1994). Thioperamide, the selective histamine $\mathrm{H} 3$ receptor antagonist, attenuates stimulant-induced locomotor activity in the mouse. Eur. J. Pharmacol. 259 (2), 107-114. doi: 10.1016/0014-2999(94) 90498-7

Coruzzi, G., Adami, M., Guaita, E., de Esch, I. J., and Leurs, R. (2007). Antiinflammatory and antinociceptive effects of the selective histamine H4-receptor antagonists JNJ7777120 and VUF6002 in a rat model of carrageenaninduced acute inflammation. Eur. J. Pharmacol. 563 (1-3), 240-244. doi: 10.1016/j. ejphar.2007.02.026

Coruzzi, G., Adami, M., and Pozzoli, C. (2012). Role of histamine H4 receptors in the gastrointestinal tract. Front. Biosci. (Schol Ed) 4, 226-239. doi: $10.2741 / \mathrm{s} 264$

Coruzzi, G., Adami, M., Pozzoli, C., de Esch, I. J., Smits, R., and Leurs, R. (2011). Selective histamine $\mathrm{H}(3)$ and $\mathrm{H}(4)$ receptor agonists exert opposite effects against the gastric lesions induced by $\mathrm{HCl}$ in the rat stomach. Eur. J. Pharmacol. 669 (1-3), 121-127. doi: 10.1016/j.ejphar.2011.07.038

Coruzzi, G., and Bertaccini, G. (1998). Histamine H3 receptors and gastric acid secretion. Gastroenterology 115 (1), 245-247. doi: 10.1016/S0016-5085(98) 70404-4

Coruzzi, G., Morini, G., Adami, M., and Grandi, D. (2001). Role of histamine $\mathrm{H} 3$ receptors in the regulation of gastric functions. J. Physiol. Pharmacol. 52 (4 Pt 1), 539-553.

Ferrada, C., Ferre, S., Casado, V., Cortes, A., Justinova, Z., Barnes, C., et al. (2008). Interactions between histamine $\mathrm{H} 3$ and dopamine D2 receptors and the implications for striatal function. Neuropharmacology 55 (2), 190-197. doi: 10.1016/j.neuropharm.2008.05.008

Ferrada, C., Moreno, E., Casado, V., Bongers, G., Cortes, A., Mallol, J., et al. (2009). Marked changes in signal transduction upon heteromerization of 
dopamine D1 and histamine H3 receptors. Br. J. Pharmacol. 157 (1), 64-75. doi: 10.1111/j.1476-5381.2009.00152.x

Garbarg, M., Arrang, J. M., Rouleau, A., Ligneau, X., Tuong, M. D., Schwartz, J. C., et al. (1992). S-[2-(4-imidazolyl) ethyl] isothiourea, a highly specific and potent histamine H3 receptor agonist. J. Pharmacol. Exp. Ther. 263 (1), 304-310.

Grandi, D., Shenton, F. C., Chazot, P. L., and Morini, G. (2008). Immunolocalization of histamine $\mathrm{H} 3$ receptors on endocrine cells in the rat gastrointestinal tract. Histol. Histopathol. 23 (7), 789-798. doi: 10.14670/HH-23.789

Hancock, A. A., Esbenshade, T. A., Krueger, K. M., and Yao, B. B. (2003). Genetic and pharmacological aspects of histamine $\mathrm{H} 3$ receptor heterogeneity. Life Sci. 73 (24), 3043-3072. doi: 10.1016/j.lfs.2003.06.003

Kuna, L., Jakab, J., Smolic, R., Raguz-Lucic, N., Vcev, A., and Smolic, M. (2019). Peptic ulcer disease: a brief review of conventional therapy and herbal treatment options. J. Clin. Med. 8 (2), 1-19. doi: 10.3390/jcm8020179

Lazewska, D., and Kiec-Kononowicz, K. (2018). Progress in the development of histamine $\mathrm{H} 3$ receptor antagonists/inverse agonists: a patent review (20132017). Expert Opin. Ther. Pat. 28 (3), 175-196. doi: 10.1080/13543776.2018. 1424135

Leurs, R., Chazot, P. L., Shenton, F. C., Lim, H. D., and de Esch, I. J. (2009). Molecular and biochemical pharmacology of the histamine $\mathrm{H} 4$ receptor. $\mathrm{Br}$. J. Pharmacol. 157 (1), 14-23. doi: 10.1111/j.1476-5381.2009.00250.x

Lim, H. D., van Rijn, R. M., Ling, P., Bakker, R. A., Thurmond, R. L., and Leurs, R. (2005). Evaluation of histamine H1-, H2-, and H3-receptor ligands at the human histamine $\mathrm{H} 4$ receptor: identification of 4-methylhistamine as the first potent and selective H4 receptor agonist. J. Pharmacol. Exp. Ther. 314 (3), 1310-1321. doi: 10.1124/jpet.105.087965

Lin, J. S., Dauvilliers, Y., Arnulf, I., Bastuji, H., Anaclet, C., Parmentier, R., et al. (2008). An inverse agonist of the histamine $\mathrm{H}(3)$ receptor improves wakefulness in narcolepsy: studies in orexin-/- mice and patients. Neurobiol. Dis. 30 (1), 74-83. doi: 10.1016/j.nbd.2007.12.003

Lin, J. S., Sergeeva, O. A., and Haas, H. L. (2011). Histamine H3 receptors and sleep-wake regulation. J. Pharmacol. Exp. Ther. 336 (1), 17-23. doi: 10.1124/ jpet.110.170134

Lovenberg, T. W., Roland, B. L., Wilson, S. J., Jiang, X., Pyati, J., Huvar, A., et al. (1999). Cloning and functional expression of the human histamine $\mathrm{H} 3$ receptor. Mol. Pharmacol. 55 (6), 1101-1107. doi: 10.1124/mol.55.6.1101

Malmberg-Aiello, P., Ipponi, A., Blandina, P., Bartolini, L., and Schunack, W. (2003). Pro-cognitive effect of a selective histamine H1-receptor agonist, 2-(3-trifluoromethylphenyl)histamine, in the rat object recognition test. Inflamm. Res. 52 Suppl 1, S33-S34. doi: 10.1007/s000110300042

Marquez-Gomez, R., Robins, M. T., Gutierrez-Rodelo, C., Arias, J. M., Olivares-Reyes, J. A., van Rijn, R. M., et al. (2018). Functional histamine H3 and adenosine A2A receptor heteromers in recombinant cells and rat striatum. Pharmacol. Res. 129, 515-525. doi: 10.1016/j.phrs.2017.11.036

Mercer D.W., Cross J. M., Barreto, J. C., Strobel, N. H. P., Russell, D. H., and Miller, T. A. (1995). Cholecystokinin is a potent protective agent against alcohol-induced gastric injury in the rat. Dig. Dis. Sci. 40, 651-660. doi: 10.1007/BF02064386

Moreno, E., Hoffmann, H., Gonzalez-Sepulveda, M., Navarro, G., Casado, V., Cortes, A., et al. (2011). Dopamine D1-histamine H3 receptor heteromers provide a selective link to MAPK signaling in GABAergic neurons of the direct striatal pathway. J. Biol. Chem. 286 (7), 5846-5854. doi: 10.1074/jbc. M110.161489

Morini, G., Becchi, G., Shenton, F. C., Chazot, P. L., and Grandi, D. (2008a). Histamine $\mathrm{H} 3$ and $\mathrm{H} 4$ receptors are expressed on distinct endocrine cell types in the rat fundic mucosa. Inflamm. Res. 57 Suppl 1, S57-S58. doi: 10.1007/ s00011-007-0628-9

Morini, G., Comini, M., Rivara, M., Rivara, S., Bordi, F., Plazzi, P. V., et al. (2008b). Synthesis and structure-activity relationships for biphenyl H3 receptor antagonists with moderate anti-cholinesterase activity. Bioorg. Med. Chem. 16 (23), 9911-9924. doi: 10.1016/j.bmc.2008.10.029

Morini, G., Grandi, D., Arcari, M. L., Galanti, G., and Bertaccini, G. (1997). Histological effect of (R)-alpha-methylhistamine on ethanol damage in rat gastric mucosa: influence on mucus production. Dig. Dis. Sci. 42 (5), $1020-$ 1028. doi: $10.1023 / \mathrm{A}: 1018841204104$

Morini, G., Grandi, D., and Bertaccini, G. (1995a). (R)-alpha-methylhistamine inhibits ethanol-induced gastric lesions in the rat: involvement of histamine H3 receptors? Digestion 56 (2), 145-152. doi: 10.1159/000201234
Morini, G., Grandi, D., and Bertaccini, G. (1995b). Stimulation of gastric acid secretion by (R)-alpha-methylhistamine in the rat: influence of the increased gastric juice volume on ethanol-induced lesions. Inflamm. Res. 44 Suppl 1, S106-S107. doi: 10.1007/BF01674419

Morini, G., Grandi, D., Stark, H., and Schunack, W. (2000). Histamine H(3)receptor antagonists inhibit gastroprotection by (R)-alpha-methylhistamine in the rat. Br. J. Pharmacol. 129 (8), 1597-1600. doi: 10.1038/sj.bjp.0703249

Nishida, A., Takinami, Y., Yuki, H., Kobayashi, A., Akuzawa, S., Kamato, T., et al. (1994). YM022 [(R)-1-[2,3-dihydro-1-(2'-methylphenacyl)-2-oxo-5-phenyl1H-1,4-benzodiazepin-3-yl]-3-(3-methylphenyl)urea], a potent and selective gastrin/cholecystokinin-B receptor antagonist, prevents gastric and duodenal lesions in rats. J. Pharmacol. Exp. Ther. 270 (3), 1256-1261.

Palle, S., Kanakalatha, A., and Kavitha, C. N. (2018). Gastroprotective and antiulcer effects of celastrus paniculatus seed oil against several gastric ulcer models in rats. J. Diet Suppl. 15 (4), 373-385. doi: 10.1080/19390211.2017.1349231

Panula, P., Chazot, P. L., Cowart, M., Gutzmer, R., Leurs, R., Liu, W. L., et al. (2015). International union of basic and clinical pharmacology. xcviii. histamine receptors. Pharmacol. Rev. 67 (3), 601-655. doi: 10.1124/ pr.114.010249

Rodriguez-Ruiz, M., Moreno, E., Moreno-Delgado, D., Navarro, G., Mallol, J., Cortes, A., et al. (2017). Heteroreceptor complexes formed by dopamine d1, histamine $\mathrm{h} 3$, and $\mathrm{n}$-methyl-d-aspartate glutamate receptors as targets to prevent neuronal death in alzheimer's disease. Mol. Neurobiol. 54 (6), 4537 4550. doi: 10.1007/s12035-016-9995-y

Sadek, B., Kuder, K., Subramanian, D., Shafiullah, M., Stark, H., Lazewska, D., et al. (2014a). Anticonvulsive effect of nonimidazole histamine H3 receptor antagonists. Behav. Pharmacol. 25 (3), 245-252. doi: 10.1097/FBP. 0000000000000042

Sadek, B., Saad, A., Latacz, G., Kuder, K., Olejarz, A., Karcz, T., et al. (2016a). Non-imidazole-based histamine $\mathrm{H} 3$ receptor antagonists with anticonvulsant activity in different seizure models in male adult rats. Drug Des. Devel. Ther. 10, 3879-3898. doi: 10.2147/DDDT.S116192

Sadek, B., Saad, A., Sadeq, A., Jalal, F., and Stark, H. (2016b). Histamine H3 receptor as a potential target for cognitive symptoms in neuropsychiatric diseases. Behav. Brain Res. 312, 415-430. doi: 10.1016/j.bbr.2016.06.051

Sadek, B., Saad, A., Schwed, J. S., Weizel, L., Walter, M., and Stark, H. (2016c). Anticonvulsant effects of isomeric nonimidazole histamine $\mathrm{H} 3$ receptor antagonists. Drug Des. Devel. Ther. 10, 3633-3651. doi: 10.2147/DDDT.S114147

Sadek, B., Saad, A., Subramanian, D., Shafiullah, M., Lazewska, D., and KiecKononowiczc, K. (2015). Anticonvulsant and procognitive properties of the non-imidazole histamine $\mathrm{H} 3$ receptor antagonist DL77 in male adult rats. Neuropharmacology 106, 46-55. doi: 10.1016/j.neuropharm.2015.10.023

Sadek, B., Schwed, J. S., Subramanian, D., Weizel, L., Walter, M., Adem, A., et al. (2014b). Non-imidazole histamine H3 receptor ligands incorporating antiepileptic moieties. Eur. J. Med. Chem. 77, 269-279. doi: 10.1016/j.ejmech. 2014.03.014

Sadek, B., Shehab, S., Wiecek, M., Subramanian, D., Shafiullah, M., KiecKononowicz, K., et al. (2013). Anticonvulsant properties of histamine H3 receptor ligands belonging to $\mathrm{N}$-substituted carbamates of imidazopropanol. Bioorg. Med. Chem. Lett. 23 (17), 4886-4891. doi: 10.1016/j.bmcl.2013.06.075

Sadek, B., and Stark, H. (2015). Cherry-picked ligands at histamine receptor subtypes. Neuropharmacology 106, 56-73. doi: 10.1016/j.neuropharm.2015.11.005

Sander, L. E., Lorentz, A., Sellge, G., Coeffier, M., Neipp, M., Veres, T., et al. (2006). Selective expression of histamine receptors H1R, H2R, and H4R, but not H3R, in the human intestinal tract. Gut 55 (4), 498-504. doi: 10.1136/ gut.2004.061762

Schwartz, J. C., Morisset, S., Rouleau, A., Ligneau, X., Gbahou, F., Tardivel-Lacombe, J., et al. (2003). Therapeutic implications of constitutive activity of receptors: the example of the histamine H3 receptor. J. Neural. Transm. Suppl. (64), 1-16. doi: 10.1007/978-3-7091-6020-6_1

Shay, H., Komarov, S. A., Fels, S. S., Meranze, D., Gruenstein, M., and Siplet, H. (1945). A simple method for the uniform production of gastric ulceration. Gastroenterology 5, 43-61.

Shenton, F. C., Hann, V., and Chazot, P. L. (2005). Evidence for native and cloned H3 histamine receptor higher oligomers. Inflamm. Res. 54 Suppl 1, S48-S49. doi: 10.1007/s00011-004-0422-x

Soldani, G., Intorre, L., Bertini, S., Luchetti, E., Coruzzi, G., and Bertaccini, G. (1994). Regulation of gastric acid secretion by histamine H3 receptors in 
the dog: an investigation into the site of action. Naunyn Schmiedebergs Arch. Pharmacol. 350 (2), 218-223. doi: 10.1007/BF00241100

Soldani, G., Mengozzi, G., Intorre, L., De Giorgi, G., Coruzzi, G., and Bertaccini, G. (1993). Histamine H3 receptor-mediated inhibition of gastric acid secretion in conscious dogs. Naunyn Schmiedebergs Arch. Pharmacol. 347 (1), 61-65. doi: 10.1007/BF00168773

Soll, A. H., and Walsh, J. H. (1979). Regulation of gastric acid secretion. Annu. Rev. Physiol. 41, 35-53. doi: 10.1146/annurev.ph.41.030179.000343

Thurmond, R. L., Desai, P. J., Dunford, P. J., Fung-Leung, W. P., Hofstra, C. L., Jiang, W., et al. (2004). A potent and selective histamine $\mathrm{H} 4$ receptor antagonist with anti-inflammatory properties. J. Pharmacol. Exp. Ther. 309 (1), 404-413. doi: 10.1124/jpet.103.061754

Thurmond, R. L., Gelfand, E. W., and Dunford, P. J. (2008). The role of histamine H1 and $\mathrm{H} 4$ receptors in allergic inflammation: the search for new antihistamines. Nat. Rev. Drug Discov. 7 (1), 41-53. doi: 10.1038/nrd2465

Varga, C., Horvath, K., Berko, A., Thurmond, R. L., Dunford, P. J., and Whittle, B. J. (2005). Inhibitory effects of histamine H4 receptor antagonists on experimental colitis in the rat. Eur. J. Pharmacol. 522 (1-3), 130-138. doi: 10.1016/j.ejphar.2005.08.045

Vollinga, R. C., de Koning, J. P., Jansen, F. P., Leurs, R., Menge, W. M., and Timmerman, H. (1994). A new potent and selective histamine H3 receptor agonist, 4-(1H-imidazol-4-ylmethyl) piperidine. J. Med. Chem. 37 (3), 332333. doi: $10.1021 / \mathrm{jm} 00029 \mathrm{a} 002$

Vuyyuru, L., and Schubert, M. L. (1997). Histamine, acting via H3 receptors, inhibits somatostatin and stimulates acid secretion in isolated mouse stomach. Gastroenterology 113 (5), 1545-1552. doi: 10.1053/gast.1997.v113. pm9352856
Wiecek, M., Kottke, T., Ligneau, X., Schunack, W., Seifert, R., Stark, H., et al. (2011). N-Alkenyl and cycloalkyl carbamates as dual acting histamine $\mathrm{H} 3$ and H4 receptor ligands. Bioorg. Med. Chem. 19 (9), 2850-2858. doi: 10.1016/j. bmc.2011.03.046

Yokotani, K., Murakami, Y., Okada, S., Wang, M., and Nakamura, K. (2000). Histamine $\mathrm{H}(3)$ receptor-mediated inhibition of endogenous acetylcholine release from the isolated, vascularly perfused rat stomach. Eur. J. Pharmacol. 392 (1-2), 23-29. doi: 10.1016/S0014-2999(00)00085-6

Yokoyama, H., Onodera, K., Iinuma, K., and Watanabe, T. (1993). Effect of thioperamide, a histamine $\mathrm{H} 3$ receptor antagonist, on electrically induced convulsions in mice. Eur. J. Pharmacol. 234 (1), 129-133. doi: 10.1016/00142999(93)90717-V

Zampeli, E., and Tiligada, E. (2009). The role of histamine H4 receptor in immune and inflammatory disorders. Br. J. Pharmacol. 157 (1), 24-33. doi: $10.1111 / j .1476-5381.2009 .00151 . x$

Conflict of Interest Statement: The authors declare that the research was conducted in the absence of any commercial or financial relationships that could be construed as a potential conflict of interest.

Copyright (ङ 2019 Bastaki, Amir, Więcek, Kieć-Kononowicz and Sadek. This is an open-access article distributed under the terms of the Creative Commons Attribution License (CC BY). The use, distribution or reproduction in other forums is permitted, provided the original author(s) and the copyright owner(s) are credited and that the original publication in this journal is cited, in accordance with accepted academic practice. No use, distribution or reproduction is permitted which does not comply with these terms. 